\title{
India's Nuclear Doctrine: A Case of Strategic Dissonance or Deliberate Ambiguity
}

\section{Dr Adil Sultan*}

\begin{abstract}
India's ongoing nuclear modernisation does not seem compatible with its declared nuclear doctrine of 2003. Several influential voices from within the country have argued for the need to review its nuclear posture. As a consequence, and to restore the credibility of its deterrence posture, some former senior Indian decision-makers have hinted that the country may have already moved from its traditional posture of No First Use (NFU) and could possibly contemplate a comprehensive first-strike against Pakistan. This potential shift in India's nuclear posture, along with operationalisation of second-strike capability, suggest that India may have drifted away from its stated policy of Credible Minimum Deterrence (CMD). It is not yet clear whether this shift is real, intended to maintain deliberate ambiguity, or else a result of prevailing dissonance within India's strategic elite. The resultant discord between its declaratory position and its ongoing developments may force Pakistan to take remedial measures that could lead to action-reaction syndrome, thus, causing instability in South Asia.
\end{abstract}

Keywords: India, Credible Minimum Deterrence, Nuclear Modernisation, Strategic Stability, Arms Race.

\footnotetext{
* The author is a Visiting Research Fellow at King's College London, United Kingdom and has worked at the Strategic Plans Division (SPD), Islamabad, Pakistan for over 13 years. The views expressed are his own and do not necessarily reflect the institutional position. He can be contacted at: adilsultan66@ hotmail.com.
}

@2018 by the Islamabad Policy Research Institute.

IPRI Journal —XVIII (2): 26-52.

https://doi.org/10.31945/iprij.180202. 


\section{Introduction}

I ndia's Draft Nuclear Doctrine (DND) of 1999 that was later updated, and formally released as the country's official nuclear policy in January 2003, contained several inconsistencies. Statements made by senior members of the Nuclear Command Authority (NCA) questioning India's commitment to the No First Use (NFU), while others arguing for a nuclear first-strike against Pakistan, ${ }^{1}$ have made it more difficult to interpret the country's intent, which could also have an adverse effect on the credibility of its own deterrence posture. One knowledgeable former official had earlier claimed that the 2003 doctrine was not necessarily a complete document, and there were parts of it that were never made public. ${ }^{2}$ This could possibly be to assuage growing internal criticism within India, or else, India might have two separate sets of doctrine - a morally defensible declaratory policy with the NFU commitment for peace time; and a nuclear war-fighting doctrine for a crisis with its principal adversary, Pakistan.

These conflicting statements could be an outcome of the prevalent discord within India's strategic enclave, or else, an attempt to maintain deliberate ambiguity about the country's emerging nuclear posture. Neither scenario bodes well for South Asia. In a nuclear contest, mixed signals could trigger unintended responses that could lead to an actionreaction syndrome, and therefore have adverse implications for regional deterrence stability.

Over the past few years, India may have reoriented its security interests and could be contemplating the decoupling of its nuclear

${ }^{1}$ Max Fisher, "India, Long at Odds with Pakistan, May be Rethinking Nuclear First Strikes," New York Times, March 31, 2017,

https://www.nytimes.com/2017/03/31/world/asia/india-long-at-odds-with-pakistan-maybe-rethinking-nuclear-first-strikes.html.

2 Shyam Saran, "Is India's Nuclear Deterrent Credible?" (speech, Habitat Centre, New Delhi, April 24, 2013), Arms Control Wonk,

https://www.armscontrolwonk.com/files/2013/05/Final-Is-Indias-Nuclear-DeterrentCredible-rev1-2-1-3.pdf. India's former Chairman of the National Security Advisory Board in a 2013 policy statement said that there are parts of the Indian doctrine that have not been made public. 
strategy, i.e., to pursue assured retaliation against China and achieve escalation dominance towards Pakistan. ${ }^{3}$ This is likely to further complicate the regional deterrence matrix and raise more questions about India's evolving strategic thinking. How would India de-hyphenate its nuclear postures, while maintaining the NFU commitment against one adversary (China) and retaining the option of a first-strike ${ }^{4}$ or a first use (FU) against the other (Pakistan)? Can India maintain a posture of a massive or assured retaliation against China, and a counterforce first-strike option against Pakistan? How would India ensure credibility of its minimum deterrence posture against China, if it also remains minimum towards Pakistan? And, finally how would India 'operationalise ${ }^{, 5}$ and integrate nuclear weapons (NWs) in its military strategy against two different adversaries?

To discuss some of the issues highlighted above, this article would provide an overview of India's nuclear drivers that also impact its declaratory nuclear policy. A comparison of the changes between the 1999 DND and the 2003 doctrine would help understand the transformation in India's nuclear policy that apparently seem insignificant, but could have implications for the regional deterrence environment. The next section deliberates upon doctrinal ambiguities within India, caused by the statements made by its senior decision-makers due to its ongoing nuclear developments. Before concluding, a discussion of India's nuclear management structure would highlight the complexities of the country's decision-making process, which is a result of bureaucratic interests and also due to internal discord within India's strategic enclave.

\footnotetext{
${ }^{3}$ Vipin Narang, "Beyond the Nuclear Threshold: Causes and Consequences of First Use" (presentation at Carnegie International Nuclear Policy Conference, Washington, D.C., March 20-21, 2017), YouTube, https://youtu.be/ChdTSSRIXB8; and Muhammad Faisal, Tanvi Kulkarni, Ruhee Neog and Saima Aman Sial "\#NUKEFEST2017 Hot Takes: Potential Indian Nuclear First Use?" South Asian Voices, March 20, 2017, https://southasianvoices.org/sav-dc-nukefest2017-potential-indian-nuclear-first-use/.

4 Terminology used by India's former National Security Advisor (NSA) Shivshankar Menon.

5 Operationalisation involves integration of nuclear weapons into overall military posture with clearly defined roles and responsibilities of nuclear command structure and strategic forces.
} 


\section{Impact of Drivers on the Nuclear Doctrine}

Nuclear weapons (NWs) remain a potent equaliser, especially for countries entangled in an asymmetric military equilibrium, and faced with an existential threat from their adversaries. In the absence of such a threat, it may be difficult for states to justify their nuclear acquisition and establish credibility of their deterrence postures. India possibly faces a similar dilemma.

India started its nuclear pursuit in the early $1950 \mathrm{~s}^{6}$ when it had no existential threat to its national security. By the late 1950s, the country arguably acquired the potential to build NWs, ${ }^{7}$ which predates its first military crisis with China in 1962. After the Chinese nuclear test of 1964, India did consider building its own nuclear deterrence but opted to wait for ten years before testing its first nuclear device in 1974, and labelled it a Peaceful Nuclear Explosion (PNE). ${ }^{8}$ It is, therefore, not necessarily a result of an existential threat to its national security.

The 1974 nuclear test was more likely guided by domestic political considerations to help Prime Minister Indira Gandhi regain her credibility at the domestic front. Subsequently, the Indian Government did attempt to conduct more tests, but was prevented in doing so by the United States (US) after it picked up the preparations from the satellite imagery in 1995. ${ }^{9}$ Towards the late 1990s, two major factors - the US' tilt towards India and the expected entry into force of the Comprehensive Nuclear-

${ }^{6}$ Naeem Salik, The Genesis of South Asian Deterrence: Pakistan's Perspective (Karachi: Oxford University Press, 2009), 15.

${ }^{7}$ Homi J. Bhabha, considered the father of India's nuclear programme, stated in 1958 that India can build a bomb in 18 months if the political leadership gives a go-ahead. While his claim remains questionable, it highlights that India was already on the path to build nuclear weapons before its first military crisis with China.

${ }^{8}$ It needs to be pointed out that very few states embarked upon NWs programme so soon after independence. Except for South Africa and Israel, there is no other example of a country pursuing NWs in their early period. Libya, North Korea or Iran did not start their nuclear programmes in the 1950s.

9 "US Detected Indian Nuclear Test Build up at Pokhran in 1995," Economic Times, February 23, 2013, https://economictimes.indiatimes.com/news/politics-and-nation/usdetected-indian-nuclear-test-buildup-at-pokhran-in-1995/articleshow/18636491.cms. 
Test-Ban Treaty (CTBT), may have encouraged the BJP Government to fulfill its electoral promise, and formally declare the country as a Nuclear Weapon State (NWS) in 1998. Prime Minister Vajpayee in his statement termed it as the "due right of one-sixth of the humankind." 10

After becoming a declared nuclear power, India assumed morally defensible commitments of NFU and 'minimum' deterrence in its DND of 1999, and the subsequent 2003 doctrine. This reflects the country's preference to utilise NWs as an instrument of prestige rather than for deterrence against an external threat.

The country's NWs programme is mostly influenced by its desire to be reckoned as a major power. 'Prestige' seems to be the overriding factor, while 'domestic politics' and 'security' may have also contributed in its nuclear choices, but were not necessarily the primary drivers. ${ }^{11}$ India's policy-makers, however, strongly contest this conclusion since this could undermine the credibility of its deterrence posture. Owing to the inherent conflict between the country's declaratory policy and its ongoing modernisation developments, there is a growing perception amongst outside observers that India lacks a credible theory of how NWs might be used other than as an instrument of national pride and propaganda. ${ }^{12}$

\footnotetext{
${ }^{10}$ Shri Atal Bihari Vajpayee, "Suo Motu Statement by Prime Minister Shri Atal Bihari Vajpayee in Parliament" (speech, New Delhi, May 27, 1998), Nuclear Age Peace Foundation, http://www.nuclearfiles.org/menu/key-issues/nuclearweapons/issues/policy/indian-nuclear-policy/suo-motu-statement-pm.html.

${ }^{11}$ For better understanding of proliferation drivers, see, Scott D. Sagan, "Why Do States Build Nuclear Weapons? Three Models in Search of a Bomb," in Going Nuclear: Nuclear Proliferation and International Security in the $21^{\text {st }}$ Century, An International Security Reader, eds., Michael E. Brown, Owen R. Coté Jr., Sean M. Lynn-Jones, Steven E. Miller and Marengo Research Llc. (London: The MIT Press, 2010).

12 This perception is being acknowledged by India's senior decision-makers. For details, see, Saran, "Is India's Nuclear Deterrent Credible?" 7.
} 


\section{India's Nuclear Doctrines}

\section{Draft Nuclear Doctrine (DND) 1999}

India released its DND on August 17, 1999 with an aim to restore public confidence in the country's deterrence capability since NWs could not prevent a military crisis with Pakistan. Key elements of the DND that also became the basis for the subsequent draft committed India to:

- $\quad$ Pursue CMD posture as per the policy of 'retaliation only'.

- Any threat of use of NWs against India shall invoke measures to counter the threat.

- Any nuclear attack on India and its forces shall result in punitive retaliation with NWs to inflict damage unacceptable to the aggressor.

- $\quad$ India will not be the first to initiate a nuclear strike, but will respond with punitive retaliation should deterrence fail.

- $\quad$ NFU would remain India's underlying commitment. ${ }^{13}$

\section{The 2003 Press Release}

India released its official nuclear policy on January 4, 2003 immediately after its second military crisis with Pakistan in the post-1998 period. This could have been an attempt to deflect domestic criticism, since India's political and military leadership remained in a state of 'strategic paralysis' and could not take any punitive measures despite enjoying significant conventional military advantage. The 2003 doctrine reiterated some of the key elements from the 1999 draft, but contained several inconsistencies that are difficult to corroborate with India's ongoing nuclear developments. In fact, statements made by senior officials have further compounded India's dilemma to establish the credibility of its declaratory

${ }^{13}$ Ministry of External Affairs, GoI, Draft Report of National Security Advisory Board on Indian Nuclear Doctrine (Government of India, 1999), https://mea.gov.in/in-focusarticle.htm?18916/Draft+Report+of+National+Security+Advisory+Board+on+Indian+N uclear+Doctrine. 
policy. One of the senior officials had also hinted that the 2003 draft was not necessarily a complete document, and that there are parts of it that were not shared with the public. ${ }^{14}$ In November 2016, India's thenDefence Minister, while arguing against providing transparency on nuclear doctrine had stated 'having a written down policy on the use of NWs would mean giving away strength. ${ }^{, 15}$

Some of the main clauses from the 2003 document that need deeper reflection to bring clarity on India's intent include its promise of: ${ }^{16}$

- $\quad$ Building and maintaining a credible minimum deterrent.

- A posture of $N F U$ - NWs will only be used in retaliation against a nuclear attack on Indian territory, or on Indian forces anywhere.

- Nuclear retaliation to a first-strike will be massive and designed to inflict unacceptable damage.

- $\quad$ In the event of major attack against India, or on Indian forces anywhere, by biological or chemical weapons, India will retain the option of retaliating with NWs.

${ }^{14}$ Saran, "Is India's Nuclear Deterrent Credible?" 5.

15 "Why Bind Ourselves to 'No First Use Policy', Says Defence Minister Parrikar on India's Nuclear Doctrine," Times of India, November 10, 2016,

https://timesofindia.indiatimes.com/india/Having-a-stated-nuclear-policy-means-givingaway-strength-says-Parrikar/articleshow/55357107.cms.

${ }^{16}$ Ministry of External Affairs, Government of India, "The Cabinet Committee on Security Reviews [O]Perationalization of India's Nuclear Doctrine" press release, January 4, 2003, http://www.mea.gov.in/press-releases.htm?dtl/20131/The+Cabinet+Committee+ on+Security+Reviews+perationalization+of+Indias+Nuclear+Doctrine. 
India's Nuclear Doctrine:

A Case of Strategic Dissonance or Deliberate Ambiguity

\section{Table-1}

Brief Comparison of DND and 2003 Press Release

\begin{tabular}{|c|c|c|}
\hline 1999 DND & 2003 Press Release & Difference \\
\hline CMD & CMD & No change \\
\hline $\begin{array}{l}\text { 'Punitive } \\
\text { Retaliation' only } \\
\text { to inflict } \\
\text { unacceptable } \\
\text { damage }\end{array}$ & $\begin{array}{l}\text { 'Massive retaliation' to } \\
\text { inflict unacceptable } \\
\text { damage }\end{array}$ & $\begin{array}{l}\text { Shifted from 'punitive' to } \\
\text { 'massive' }\end{array}$ \\
\hline $\begin{array}{l}\text { NWs may be used } \\
\text { [only] against the } \\
\text { threat of use of } \\
\text { NWs }\end{array}$ & $\begin{array}{l}\text { NWs can be used in } \\
\text { response to use of chemical } \\
\text { or biological weapons } \\
\text { against India or Indian } \\
\text { forces anywhere }\end{array}$ & $\begin{array}{l}\text { Scope extended to include } \\
\text { nuclear response, even if } \\
\text { chemical or biological } \\
\text { weapons are used }\end{array}$ \\
\hline $\begin{array}{l}\text { NFU - Will 'not' } \\
\text { be the first to } \\
\text { initiate nuclear } \\
\text { strike }\end{array}$ & $\begin{array}{l}\text { NFU - Will 'only' be used } \\
\text { in retaliation against } \\
\text { nuclear attack against } \\
\text { Indian territory or Indian } \\
\text { forces anywhere }\end{array}$ & $\begin{array}{l}\text { Both reiterate the NFU } \\
\text { posture, but the } 2003 \\
\text { document also promises } \\
\text { nuclear retaliation even if } \\
\text { Indian forces are attacked by } \\
\text { NWs outside of its own } \\
\text { territory }\end{array}$ \\
\hline
\end{tabular}

Source: Author's own.

\section{Ambiguities in India's Nuclear Doctrine}

\section{Credibility of India's CMD Posture?}

India maintains that it will continue to follow the policy of CMD without being specific about who is the intended deterree. Soon after the 1998 tests, India's Defence Minister had termed China, not Pakistan as India's potential enemy number one, ${ }^{17}$ but subsequent military developments

${ }^{17}$ John F. Burns, "India Sets 3 Nuclear Blasts, Defying a Worldwide Ban; Tests Bring a Sharp Outcry," New York Times, May 12, 1998,

https://www.nytimes.com/1998/05/12/world/india-sets-3-nuclear-blasts-defying-aworldwide-ban-tests-bring-a-sharp-outcry.html. 
mostly remained Pakistan-specific, and may not be sufficient to deal with the perceived threat from China. If India continues to expand its nuclear capability to attain a credible deterrence posture against China, it would not remain minimum towards Pakistan. ${ }^{18}$

To deal with this 'minimum-credible' paradox accentuated by two different dyadic deterrence equations, India could possibly consider decoupling of its nuclear strategy, ${ }^{19}$ to help justify its nuclear build-up against the 'projected' threat (China), while providing options to pursue more aggressive strategies against its principal adversary (Pakistan). This, in theory, may help address some of the grey areas that continue to undermine the credibility of India's nuclear posture, but could bring more operational challenges to deal with two conventionally asymmetric adversaries. No NWS, including the two leading nuclear super powers, has the potential to maintain multiple deterrence postures that could also be considered credible, and India is no different.

India has embarked upon an ambitious military modernisation plan $^{20}$ that includes the development and operationalisation of its nuclear triad, and a sizeable Continuous-At-Sea-Deterrence (CASD) increasing its reach beyond the Indian Ocean (IO). The country is also in the process of developing Intercontinental Ballistic Missiles (ICBMs) and Multiple Independently Targetable Reentry Vehicles (MIRVs), besides the AntiBallistic Missile (ABM) system. Combined together, these developments far exceed India's requirement of minimum deterrence, and are in contrast with its stated policy of a CMD posture.

\footnotetext{
${ }^{18}$ Vipin Narang, "Five Myths about India's Nuclear Posture," The Washington Quarterly 36, no.3 (2013): 143-147 (144), https://doi.org/10.1080/0163660X.2013.825555.

${ }^{19}$ Narang, "Beyond the Nuclear Threshold: Causes and Consequences of First Use."

${ }^{20}$ Mansoor Ahmed, "India's Nuclear Exceptionalism: Fissile Materials, Fuel Cycles and Safeguards" (paper, Belfer Center for Science and International Affairs, Harvard Kennedy School, Cambridge, 2017), http://www.academia.edu/35067647/Indias_Nuclear_Exceptionalism_Fissile_Materials_ Fuel_Cycles_and_Safeguards; and Shannon N. Kile and Hans M. Kristensen, Trends in World Nuclear Forces, 2017, fact sheet (Solna: Stockholm International Peace Research Institute, 2017), https://www.sipri.org/publications/2017/sipri-fact-sheets/trends-worldnuclear-forces-2017.
} 
India's Nuclear Doctrine:

A Case of Strategic Dissonance or Deliberate Ambiguity

The 2017 Joint Doctrine Indian Armed Forces (JDIAF) states only 'credible deterrence' capability as one of the national security objectives. ${ }^{21}$ It is not clear whether the transition from 'credible minimum' to only 'credible' is deliberate or one of the several typographical errors in the document. ${ }^{22}$ Nevertheless, the new doctrine has the approval of Chairman, Chiefs of Staff Committee (COSC), who is the administrative head of India's Strategic Forces Command (SFC) and therefore, this change cannot be ignored. It is quite possible India may want to shed the issue of quantifying its nuclear capability to help build credibility of its deterrence posture against China, and also enhance its image as an emerging global military power.

\section{From 'Punitive' to Massive Retaliation}

India's 2003 nuclear doctrine threatens 'massive retaliation' - to inflict unacceptable damage to its adversaries, which is a significant departure from its earlier commitment of a 'punitive retaliation'. Moreover, the term 'massive' itself has a connotation of using all available means by the deterrer, including the use of countervalue as well as counterforce weapons with an objective to neutralise any deterree's capacity to retaliate. It is not clear how massive use of force would guarantee only limited or unacceptable damage, and what would construe as being unacceptable by India's principal adversary Pakistan, or its perceived adversary China.

India's shift from 'punitive' to the 'massive' retaliation may also have pushed it into a commitment trap, thus, further straining the credibility of its deterrence posture. For instance, if India decides to

\footnotetext{
${ }^{21}$ Headquarters Integrated Defence Staff, Ministry of Defence, GoI, Joint Doctrine Indian Armed Forces (JDIAF), (Government of India, 2017), 3, http://bharatshakti.in/wpcontent/uploads/2015/09/Joint_Doctrine_Indian_Armed_Forces.pdf.

${ }^{22}$ Sudarshan Shrikhande, "Joint Doctrine of Indian Armed Forces - Wholly Informational, Hardly Doctrinal," Wire, May 8, 2017, https://thewire.in/government/joint-doctrineindian-armed-forces-wholly-informational-hardly-doctrinal.
} 
launch its Cold Start Doctrine (CSD) ${ }^{23}$ against Pakistan, and in response the latter decides to use its nuclear-capable Short-Range Ballistic Missile (SRBM) Nasr to deter intruding troops - would India be able to follow through its massive retaliation doctrine against limited use, or even a threat of use of NWs by Pakistan? And if it does, as is being suggested by some from the Indian side, this would not only be disproportionate but difficult to justify, especially if India is the aggressor, and has initiated the military hostility. ${ }^{24}$

It is unlikely that India would be able to follow through its doctrinal commitment of massive retaliation, especially after the introduction of SRBMs by Pakistan. India's decision-makers, however, continue to emphasise that any 'nuclear exchange once initiated would swiftly and inexorably escalate to the strategic level. ${ }^{, 25}$ These statements appear to be targeted towards the domestic and external audience, especially its regional rivals besides the major powers, and are intended to restore the credibility of India's nuclear posture. Nevertheless, if New Delhi decides to operationalise its nuclear doctrine during a military crisis, it could possibly end up into an exchange of strategic NWs from both sides.

Moreover, if a limited use of NWs has the potential of escalating to strategic weapons as the Indian planners advocate, one cannot rule out the possibility of a limited conventional military operation, like the CSD, escalating into an all-out nuclear exchange. Therefore, the role of NWs, especially in an asymmetric military equilibrium, is not only to prevent a nuclear war, but as Quinlan had observed earlier: it should help prevent all

\footnotetext{
${ }^{23}$ Ajai Shukla, "Army Chief Says Military Must Prepare for Cold Start," Business Standard, January 14, 2017, https://www.business-standard.com/article/currentaffairs/army-chief-says-military-must-prepare-for-cold-start-117011301174_1.html. The Cold Start Doctrine (CSD) is a war-fighting doctrine introduced by India in 2004 to fight a limited war under a nuclear environment. In January 2017, India's Army Chief formally acknowledged the existence of CSD.

${ }^{24}$ Ali Ahmed, "Tit for Tat: A Nuclear Retaliation Alternative" (comment, Institute for Defense Studies and Analyses, New Delhi, 2011), https://idsa.in/idsacomments/TitforTatANuclearRetaliationAlternative031011.

${ }^{25}$ Saran, “Is India's Nuclear Deterrent Credible?” 16.
} 
wars, including a limited conventional war between nuclear armed adversaries. $^{26}$

Despite these inherent dangers of the limited use of NWs, the escalation ladder is not just a natural 'chemical' process with a predetermined sequence of events, it is guided by human choices influenced by several internal and external variables, ${ }^{27}$ which may include: the nature and genesis of the military crisis; resolve of political leadership; capability to launch pre-emptive first-strike or retaliate in the form of second-strike capability; the prevailing international environment; and a clear understanding of the adversary's pain threshold that could be construed as unacceptable.

Due to the horrific consequences of the use of NWS, there is a strong opinion that the consideration of even a limited nuclear war is dangerous, and probably, delusional. Nevertheless, their limited use remains one of the possible choices for all major powers, to avoid the option of disarming strikes for fear of equally disastrous consequences. ${ }^{28}$ The North Atlantic Treaty Organization (NATO) and the US continue to find utility in their limited use as part of their war-termination strategy. Likewise, the Russian military doctrine of 2014 also retains the possibility of limited nuclear use against large-scale conventional aggression. ${ }^{29}$ More recently, the US has also been reconsidering the option of 'mini nukes' that could make NWs more useable in the future. ${ }^{30}$

India's continued emphasis on 'massive retaliation' as the only option against any use of NWs is primarily intended to create space for its

\footnotetext{
${ }^{26}$ Michael Quinlan, Thinking about Nuclear Weapons: Principles, Problems, Prospects (New York: Oxford University Press, 2009), 21.

${ }^{27}$ Ibid., 16-17.

${ }^{28}$ Alexey Arbatov, "Beyond the Nuclear Threshold: Russia, NATO, and Nuclear First Use" (brief, European Leadership Network, London, 2017), https://www.europeanleadershipnetwork.org/wp-content/uploads/2017/10/Beyond-theNuclear-Threshold.pdf.

${ }^{30}$ Emily Shugerman, "Trump Panel Said to be Pushing for 'Mini Nukes' to Make Nuclear Strikes Easier," Independent, September 9, 2017, https://www.independent.co.uk/news/world/americas/us-politics/trump-nuclearweapons-mini-nukes-targeted-strike-conflict-war-north-korea-russia-a7938486.html.
} 
limited conventional war-fighting doctrine by deterring Pakistan from the use or the threat of use of its SRBMs against Indian troops. The shift from punitive to massive retaliation, and the subsequent conflicting interpretations provided by various senior decision-makers indicate that India is finding it increasingly difficult to establish the credibility of its deterrence posture since it does not have the capacity to completely neutralise Pakistan's potential to inflict unacceptable damage, even if the former resorts to a pre-emptive first-strike.

\section{India's No-NFU Posture}

India's 2003 nuclear doctrine stated:

NWs will only be used in retaliation against a nuclear attack on Indian territory or on Indian forces anywhere. ${ }^{31}$

However, this had a caveat that if attacked by biological or chemical weapons, it would retain the option of retaliating with NWs. ${ }^{32}$ This effectively nullified the NFU posture commitment that had been one of the central tenets of India's declaratory nuclear policy. Some of the recent statements emanating from India suggest that the country could possibly be contemplating the option of a first-strike against Pakistan, which would be in contrast to its NFU commitment. It is not certain what would constitute a first-strike as several statements coming from India often confuse the term with 'First Use', which is essentially another term with different connotations. As per the established nuclear lexicon, 'First Use' could be intended to warn the adversary about the consequences of the failure to retreat from aggressive posturing, ${ }^{33}$ and is generally limited in

${ }^{31}$ See Article 2 (II) in, Ministry of External Affairs, Government of India, "The Cabinet Committee on Security Reviews [O[Perationalization of India's Nuclear Doctrine."

${ }^{32}$ See Article 2 (IV) in, Ministry of External Affairs, Government of India, "The Cabinet Committee on Security Reviews [O]Perationalization of India's Nuclear Doctrine."

${ }^{33}$ Lawrence Freedman, "The No-First-Use Debate and the Theory of Thresholds," in No First Use, eds., Frank Blackaby, Jozef Goldblat and Sverre Lodgaard (Stockholm: Taylor and Francis, 1984), 67. 
scope. If used in self-defence, this could be considered as legitimate. ${ }^{34}$ 'First-strike', on the other hand, aims to destroy adversary's capacity to retaliate by launching a pre-emptive nuclear strike. ${ }^{35}$ The force required to achieve the objective may be massive, thus, would fall under the purview of aggression, and is, therefore, considered unambiguously illegal. ${ }^{36}$

States with large nuclear inventories and conventional military advantage could nevertheless opt for a 'first-strike' option, as part of their 'war-winning' strategy, but this would remain a high risk alternative as the temptation to destroy the adversary's nuclear potential could end up in mutual annihilation. On the other hand, the decision of 'first use' was considered by some as part of a 'war-termination' strategy - to help limit nuclear exchange at the lower spectrum of the conflict, without risking exchange of strategic weapons.

Unlike the Cold War, India and Pakistan do not enjoy spatial luxury or have the potential to carry out disarming first-strike against each other. In a South Asian environment, even a limited counterforce first-strike by one may be construed as massive by the other, thus, putting pressure on the national leadership to skip intermediate rungs of the escalation ladder, and resort to the exchange of strategic weapons. Nevertheless, several high-ranking Indian officials, including the former Strategic Forces Commander-in-Chief Lt. Gen. B.S. Nagal, former Defence Minister Manohar Parrikar, and former National Security Advisor Shivshankar Menon - all have shown skepticism towards India's NFU posture. ${ }^{37}$ In his most recent book Menon writes:

\footnotetext{
${ }^{34}$ ICJ, Legality of the Threat or Use of Nuclear Weapons: Advisory Opinion of 8 July 1996, report (The Hague: International Court of Justice, 1996), http://www.icj-cij.org/files/case-related/95/095-19960708-ADV-01-00-EN.pdf. On legality of nuclear use in self-defence, the International Court of Justice (ICJ) Advisory Opinion of 1996 stated that it "cannot conclude definitively whether the threat or use of nuclear weapons would be lawful or unlawful in extreme circumstance of selfdefence, in which the very survival of a State would be at stake.'

${ }^{35}$ Quinlan, Thinking about Nuclear Weapons: Principles, Problems, Prospects, 17.

${ }^{36}$ Freedman, "The No-First-Use Debate and the Theory of Thresholds," 23.

${ }^{37}$ Narang, "Beyond the Nuclear Threshold: Causes and Consequences of First Use."
} 
There is potential grey area as to when India would use nuclear weapons first against another NWS. Circumstances are conceivable in which India might find it useful to strike first, for instance, against an NWS that had declared it would certainly use its weapons, and if India were certain that adversary's launch was imminent. ${ }^{38}$

According to Menon, if Pakistan uses or even contemplates the use of its Tactical Nuclear Weapons (TNWs), it would free up India from its NFU commitment to undertake a comprehensive first-strike against Pakistan. ${ }^{39}$ Earlier, Brig. (Retd.) Arun Sehgal, while delivering a public talk at the Atlantic Council in 2015, Washington, D.C. had stated that India will retain the right to take actions even against the 'threat of use' of force.

The use of NWs, even against the 'threat of use' by the adversary, is in contrast to India's NFU pledge, and thus, could be destabilising, especially since it does not have the means to verifiably conclude that their use by Pakistan is imminent. India's recent notion of a counterforce first-strike may be different from the classical definition of 'first-strike', i.e., a bolt-from-the-blue attack. ${ }^{40}$ Notwithstanding, the nomenclature and rationale provided by India's officials, it seems the country may be drifting away from its long-held position of NFU, in favour of a counterforce pre-emptive first-strike.

For India to develop its potential to launch a first-strike against Pakistan, it would need significant increase in its nuclear stockpile, besides building requisite Intelligence, Surveillance and Reconnaissance (ISR) capabilities. Without acquiring these capabilities, according to Rajagopalan, such ill-conceived statements and incredible threats, further worsen the problem of establishing credibility of the country's deterrence

\footnotetext{
${ }^{38}$ Shivshankar Menon, Choices: Inside the Making of India's Foreign Policy (Washington, D.C.: Brookings Institution Press, 2016), 110.

${ }^{39}$ Ibid., 117.

${ }^{40}$ Rajesh Rajagopalan, “India's Nuclear Strategy: A Shift to Counterforce?” (New Delhi: Observer Research Foundation, 2017), https://www.orfonline.org/expert-speak/indianuclear-strategy-shift-counterforce/.
} 
posture. ${ }^{41}$ Any shift from its earlier NFU to 'first use' or 'first-strike' could have serious political and security implications for the region. It would no longer be able to project itself as a responsible nuclear state, while the doctrinal change would most certainly compel India's adversaries, especially Pakistan, to take adequate measures to ensure the credibility of its nuclear deterrence.

\section{India's CSD and TNWS}

India launched its CSD in $2004,{ }^{42}$ which was later renamed as Proactive Operations (PAOs) strategy. The new war-fighting concept seems to be a Pakistan-specific doctrine intended to fight a limited conventional war under a nuclear environment by reducing the mobilisation time of India's military forces, while remaining below Pakistan's 'perceived' nuclear threshold. As part of this doctrine, the Indian military has reconfigured its Strike Corps into at least eight smaller division-sized Integrated Battle Groups (IBGs) with combined mechanised infantry, artillery and armour. In the event of a future military crisis, these IBGs stationed closer to the border in newly established cantonments would be expected to cross the international border and make ingress $50-80 \mathrm{~km}$ inside Pakistan's territory in a relatively short time of 72-96 hours.

The CSD was never fully endorsed by the political leadership to avoid negative focus by the international community, but the Indian military continues to refine it through regular exercises with increasing frequency. In January 2017, India's Army Chief, General Bipin Rawat confirmed the existence of $\mathrm{CSD},{ }^{43}$ thus, removing any remaining ambiguity about the existence of the new doctrine. The JDIAF released in

${ }^{41}$ Ibid.

${ }^{42}$ Walter C. Ladwig III, “A Cold Start for Hot Wars? The Indian Army's New Limited War Doctrine," International Security 32, no. 3 (2008): 158-190(162),

https://www.belfercenter.org/sites/default/files/legacy/files/IS3203_pp158-190.pdf.

${ }^{43}$ Vipin Narang, Walter C. Ladwig III, “Taking 'Cold Start' Out of the Freezer," Hindu, January 11, 2017, https://www.thehindu.com/opinion/lead/Taking-\%E2\%80\%98ColdStart\%E2\%80\%99-out-of-the-freezer/article17019025.ece; and Shukla, "Army Chief Says Military Must Prepare for Cold Start." 
April 2017 also stated enhancing military capability - 'to mobilise swiftly for an early launch to rapidly achieve tangible gains, ${ }^{44}$ - as one of the major objectives, which forms the core principle of India's CSD/ PAOs doctrine.

India's new doctrinal thinking was based on an assumption that there existed space for a blitzkrieg kind-of conventional military operation as a 'punitive' action, in response to an attack by non-state actors, allegedly sponsored by Pakistan. ${ }^{45}$ Apparently, the new doctrine did not take into consideration Pakistan's likely response options, as India's military had earlier hoped to exploit its conventional advantage while avoiding nuclear exchange.

Faced with this new challenge, Pakistan also reconfigured its conventional forces to assure a matching response. To further strengthen its military deterrence posture, Pakistan introduced its SRBMs - also known as Nasr TNW. These new developments that have been triggered mainly by India's decision to introduce CSD/ PAOs doctrine, are part of Pakistan's Full Spectrum Deterrence (FSD) posture, which has been explained by officials and scholars as not necessarily a quantitative shift, rather as a qualitative response to deal with the complete spectrum of threats, ranging between deterring a limited war through the possible use of TNWs to an all-out war through the threat of use of strategic weapons.

Amongst adversaries with conventional asymmetry, the nuclear threshold may not necessarily be an outcome of relative balance in nuclear inventories, but the prime determinant would be the relative combat performance of non-nuclear forces. ${ }^{46}$ The greater the conventional asymmetry, the greater the pressures on these forces, and more likely the possibility of an early nuclear use. India's attempt to create space for a limited war with Pakistan under a nuclear environment is, therefore, not

\footnotetext{
${ }^{44}$ Headquarters Integrated Defence Staff, Ministry of Defence, GoI, JDIAF, 33.

${ }^{45}$ Muhammad Ali Baig and Hamid Iqbal, "A Comparative Study of Blitzkrieg and Cold Start Doctrine: Lessons and Countermeasures for Pakistan," IPRI Journal XVIII, no. 1 (2018): 1-31, http://www.ipripak.org/wp-content/uploads/2018/03/art1jw2018.pdf.

${ }^{46}$ Quinlan, Thinking about Nuclear Weapons: Principles, Problems, Prospects, 16.
} 
only dangerous but also miscued since it could trigger a nuclear exchange with no meaningful outcome or advantage to the former.

Some critics of Pakistan's relatively new concept of FSD argue that it may have drifted away from its earlier policy of Credible Minimum Deterrence (CMD), which is not true. As per the statements by Pakistan's National Command Authority (NCA $)^{47}$ and the senior military leadership, it appears that the country has consciously decided to continue pursuing the policy of $\mathrm{CMD}^{48}$ Moreover, 'full spectrum' does not mean that Pakistan has embarked upon developing full range of NWs ranging between zero-yield to thermonuclear weapons. The term was coined to elaborate the complete spectrum of threats that Pakistan would like to address, starting from a limited to an all-out war. The Nasr SRBM helps Pakistan to cater for the lower end of the spectrum, thus, strengthening its overall deterrence posture and is not a nuclear war-fighting weapon.

\section{India's Nuclear 'Tit-for-Tat' Option}

Pakistan's decision to introduce SRBMs challenged the credibility of India's massive retaliation doctrine, and thus, curtailed its option of conducting a conventional war through its CSD/ PAOs strategy doctrines. India's promise of massive retaliation against limited use of NWs by Pakistan could have been viewed as disproportionate, whereas, if the former failed to follow through its doctrinal commitment, this could have undermined the credibility of its deterrence posture.

Faced with this dilemma, some Indian scholars argued that the country could possibly consider a proportionate, or a 'tit-for-tat' response $^{49}$ - to engage Pakistan at the lower spectrum of nuclear warfighting, besides retaining the option of massive retaliation for an all-out war. Introduction of Prahaar TNW by India in July 2011, immediately

\footnotetext{
${ }^{47}$ Inter Services Public Relations, Government of Pakistan, press release no. 64, February 24, 2016, https://www.ispr.gov.pk/press-release-detail.php?id=3211.

48 "Pakistan will Pursue Developing Minimum Deterrence to Counter Threats to its Security: Gen. Hayat," Dawn, August 20, 2017, https://www.dawn.com/news/1352781.

${ }^{49}$ Ahmed, "Tit for Tat: A Nuclear Retaliation Alternative."
} 
after Pakistan's test of the Nasr missile system is most likely an outcome of similar thinking. Interestingly, development of Prahaar TNW by India has largely gone unnoticed, while there remains excessive focus on Pakistan's Nasr missile system. Some have also argued that the Prahaar missile could be restricted only to a conventional role, but the press release issued by India's Press Information Bureau (PIB) had explicitly labelled the new TNW as having the capacity of carrying different types of warheads. ${ }^{50}$

India's evolving thinking on the need to develop proportionate response options against Pakistan is also reflected in a recently published book by the country's former National Security Advisor, Shivshankar Menon, who writes that:

There is nothing in the present doctrine that prevents India from responding proportionately to a nuclear attack... and [India's] doctrine speaks of punitive retaliation. ${ }^{51}$

Menon's argument of proportional response and punitive retaliation is a significant departure from India's 2003 declaratory policy of 'massive retaliation', and has triggered interesting debate at the international level. It also contradicts repeated reiterations by Indian officials that irrespective of the use of NWs (tactical or strategic), the country's nuclear retaliation will be massive. ${ }^{52}$ These new interpretations could have serious political, military and arms control implications, and highlight the need to bring clarity on India's evolving nuclear posture for a stable deterrence relationship in the region.

It is also interesting to study how similar weapons could end up playing different roles in national nuclear strategies. For example, Pakistan claims that its SRBM/ TNW Nasr is purely intended to deter India's limited war-fighting doctrine, and is, therefore, a war prevention

${ }^{50}$ Press Information Bureau, Government of India, "DRDO Launches 'PRAHAAR' Surface to Surface Tactical Missile," press release, July 21, 2011, http://www.pib.nic.in/newsite/erelease.aspx?relid=73407.

${ }^{51}$ Menon, Choices: Inside the Making of India's Foreign Policy, 110-111.

${ }^{52}$ Saran, "Is India's Nuclear Deterrent Credible?" 16. 
India's Nuclear Doctrine:

A Case of Strategic Dissonance or Deliberate Ambiguity

weapon. On the other hand, India introduced its Prahaar TNW to provide proportionate or a 'tit-for-tat' response option to its decision-makers, since the credibility of India's massive retaliation doctrine was increasingly coming under stress. This could, therefore, be seen as a war-fighting instrument at the lower spectrum of a nuclear conflict. This differential understanding of the role of TNWs on both sides is important in order to better appreciate the emerging deterrence relationship between the two South Asian nuclear neighbours that has several similarities with the Cold War model, but is also distinctly different in terms of employment of NWs.

\section{Nuclear Management in India}

India's Nuclear Command Authority (NCA) is not an independent entity, rather part of the National Security Structure (NSS), ${ }^{53}$ comprising of the Cabinet Committee on Security (CCS) and National Security Council (NSC). The CCS is responsible for all matters concerning national security, and is led by the Prime Minister. Armed Forces Chiefs and others are invited for consultations strictly on required basis. India's NSC is a parallel body with almost similar membership, and the National Security Advisor (NSA) and Deputy Chairman Planning Commission, are additional members. The NSC is assisted by the Strategic Policy Group (SPG), a committee of secretaries and the National Security Advisory Board (NSAB).

India's SFC falls under the purview of the Chairman, COSC, who is the senior most Service Chief, and is supported by Chief of Integrated Defense Staff (IDS). India has also introduced Strategic Planning Staff (SPS), similar to Pakistan's Strategic Plans Division (SPD), which is responsible for development and management of India's nuclear deterrent. SPS is a small group of 25-30 people, comprising of representatives from the three services, external affairs ministry and the scientists. It is headed by a retired SF Commander. The Strategic Armament Safety Authority

${ }^{53}$ Headquarters Integrated Defence Staff, Ministry of Defence, GoI, JDIAF, 37. 
(SASA) has also been established on the pattern of Pakistan's Security Division, which is responsible for all matters relating to safety and security of nuclear and delivery vehicles.

\section{India's National Security Structure (NSS)}

Unlike other NWSs, India does not seem to have separate strategic forces. ${ }^{54}$ Instead, the SFC comprises of representatives from the three services, apart from the civilian staff, experts from Indian Atomic Energy Commission (AEC) and Defence Research and Development Organization (DRDO). It is the NCA's operational arm and controls all nuclear warheads and delivery systems, ${ }^{55}$ which effectively puts the country's nuclear deterrent under the control of the SFC, which is a military-led entity functioning under the COSC as part of the NCA. This arrangement seems to be in contrast with the generally held perception that India maintains strict civilian control over its nuclear arsenal (see Figure 1).

${ }^{54}$ Menon, Choices: Inside the Making of India's Foreign Policy, 111.

${ }^{55}$ Headquarters Integrated Defence Staff, Ministry of Defence, GoI, JDIAF, 37. 
India's Nuclear Doctrine: A Case of Strategic Dissonance or Deliberate Ambiguity

\section{Figure-1}

\section{NSS of India}

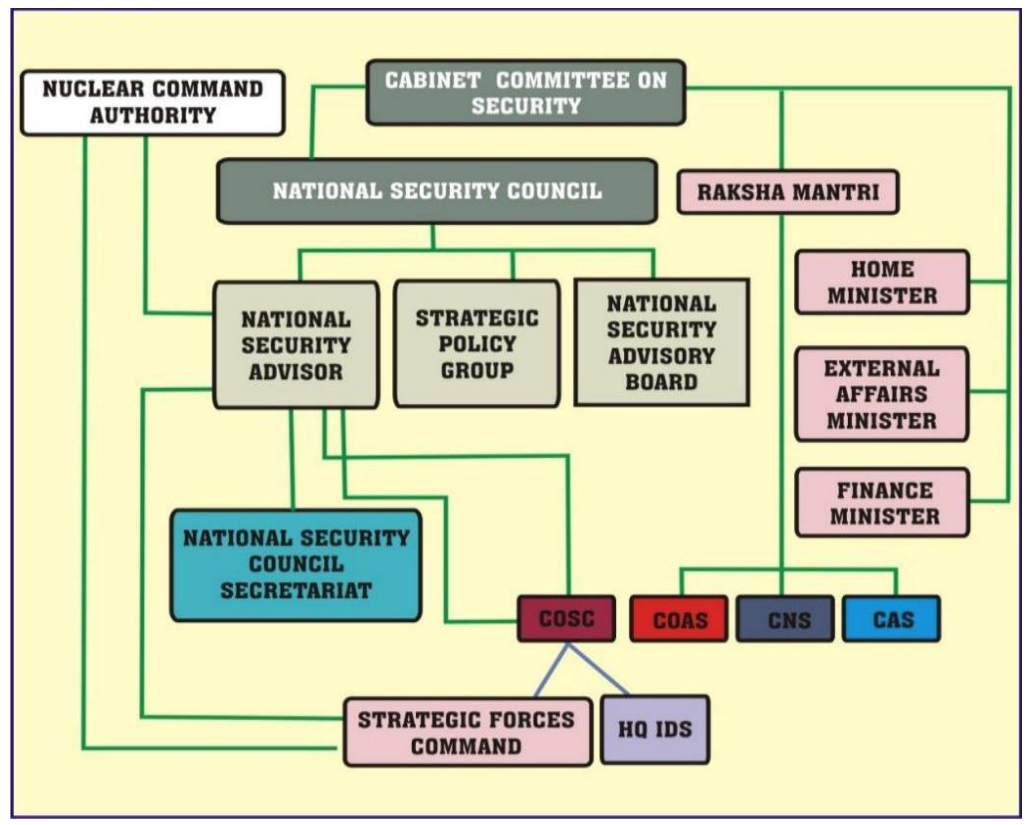

Source: Headquarters Integrated Defence Staff, Ministry of Defence, GoI, JDIAF

Moreover, the COSC is also responsible for inter-services coordination, besides management of nuclear arsenal through SFC. This duplication of role without adequate compartmentalisation between conventional and nuclear operations could be destabilising as NWs could come into play much earlier during a crisis.

India's NCA, which is part of NSS, consists of the Political Council (PC), headed by the Prime Minister and the Executive Council (EC) led by the NSA, who is also the Secretary of the PC and acts as the linkage between the two bodies. Since the senior-most Service Chief is also the Chairman of COSC, therefore, it has not been reflected separately in NCA's structure (see Table 2).

The main objectives that have been defined for India's NCA are to ensure credibility of deterrence; maintain policy of NFU; strict civilian 
control; and ensure credible retaliatory capacity. ${ }^{56}$ These elements have also been reflected in India's 2003 doctrine.

Table-2

India's Nuclear Command Authority (NCA)

\begin{tabular}{|ll|}
\hline \multicolumn{1}{|c|}{ Political Council } & \multicolumn{1}{c|}{ Executive Council } \\
\hline Prime Minister - Chairman & NSA - Chairman \\
\hline Other Members & Other Members \\
\hline Defence Minister & Services Chiefs \\
\hline Home Minister & DG DRDO \\
\hline External Affairs Minister & Chairman AEC \\
\hline Finance Minister & Secretary RAW \\
\hline NSA - Secretary & Director IB \\
\hline & C-in-C SFC - Secretary \\
\hline
\end{tabular}

Source: Arun Sehgal (presentation at seminar, Atlantic Council, Washington D.C., June 22, 2015).

The functioning of India's NCA, as part of its overall NSS, makes it a complicated exercise since several stakeholders would be required to provide their input, with some dealing with both conventional as well as nuclear operations, without compartmentalisation. This may be helpful in better appreciation of the larger picture, but it is not clear whether it would be capable of appreciating operational matters with clarity, which has been described by a former commander of India's Naval Strategic Forces Admiral Koithara, as the problem of presbyopia. ${ }^{57}$ According to Koithara, this is mainly because India's decision-makers view 'deterrence essentially as an instrument of prestige and not as an operationalised

${ }^{56}$ Ibid., 37

${ }^{57}$ Verghese Koithara, Managing India 's Nuclear Forces (New Delhi: Routledge, 2012), 11 
India's Nuclear Doctrine:

A Case of Strategic Dissonance or Deliberate Ambiguity

strategic posture, ${ }^{58}$ and, therefore, operational issues are not given credence by both the senior political and military leadership.

\section{The Discord within India's Strategic Enclave}

India's three principal stakeholders - the political, scientific and military leadership - all seem to be moving on different trajectories, once it comes to the identification of threat perception and developing appropriate response options in terms of capabilities and doctrinal concepts.

India's political leadership views NWs mainly as a symbol of prestige and a tool to project the country as a major, but at the same time, a responsible NWS. Therefore, it continues to reiterate the principle of NFU, and support global nuclear disarmament efforts. Its scientific community, on the other hand, is pursuing technological solutions against unspecified threats, including the development of ICBMs, MIRVs, BMD systems, etc., besides working on cannisterisation of missiles to reduce response time, which could be seen as moving towards higher readiness level.

The military, which is the third major stakeholder, remains an outlier once it comes to nuclear decision-making in India. It is working on a completely different trajectory to develop new war-fighting concepts without consideration about the presence of NWs in the region.

Several former senior military officers have been critical of keeping the military outside the nuclear decision-making process. Responding to this anomaly India's former Chairman of the NSAB, Shyam Saran points out that 'the military's inputs into strategic planning and execution should be enhanced to make India's nuclear deterrent more effective,' but he disagreed with the general perception that 'India's armed forces are not fully part of the strategic decision-making process, and that they play second fiddle to the civilian bureaucracy and the scientific establishment. ${ }^{59}$

${ }^{58}$ Ibid., 81.

${ }^{59}$ Saran, "Is India's Nuclear Deterrent Credible?" 9-10. 
This issue has also found resonance in the 2017 JDIAF which states:

Military professionals are experts in the use of force under the political institution of the State. Apropos, it would always be essential for the civilian authority, in consultation with military (as part of decision-making process) to decide the Military Objective and then leave it to the military professionals to decide upon the best way of achieving the objective. $^{60}$

According to Admiral (Retd.) Koithara, reluctance by India's political leadership, and the scientific community to include the military in the nuclear decision-making process, has led to 'retarded deterrence understanding' that is based on abstract and dubious assumptions. ${ }^{61}$ Due to this perpetual disconnect within India's strategic enclave, Koithara believes India has not been able to fully operationalise its nuclear forces, ${ }^{62}$ as compared to Pakistan, which may have relatively weak political, financial and technological resources, but has managed to project adequate deterrence, through appropriately tailored strategies and management structure. ${ }^{6}$

For a country that aspires to be a regional power and is making massive investments to develop both its conventional and nuclear capabilities, such shortcomings, not only undermine its own deterrence posture, but could also lead to incorrect assumptions on the other side, thus, resulting in unintended arms competition. To avoid misreading of intent, India needs to align its nuclear developments with its doctrinal

${ }^{60}$ Headquarters Integrated Defence Staff, Ministry of Defence, GoI, JDIAF, 60.

${ }^{61}$ Koithara, Managing India's Nuclear Forces, 9.

${ }^{62}$ According to Koithara 'operationalization' is different from 'readiness', and is a set of processes that readies a weapon system fully, in material, human and organisational terms, to perform its intended tasks. For details, see Koithara, Managing India's Nuclear Forces, 11.

${ }^{63}$ Ibid., 8-9. 
postulations, which at present reflect perpetual dissonance amongst its senior decision-makers.

\section{Conclusion}

Nuclear doctrines are not a fixity and could change depending upon the nature of evolving threat and technological achievements. In the absence of a credible and existential threat, it is often difficult for states to defend their nuclear policies that are not necessarily aligned with their own nuclear drivers. India's 'period doctrine' of 2003 faces such a dilemma since it has failed to evolve with new ground realities, despite the government's claim that it faces multidirectional security challenges that may require decoupling of its deterrence posture, i.e., acquiring 'escalation dominance' over Pakistan and building a capacity of 'assured retaliation' against China.

At present, the promise of responding with full force against 'any' use of NWs, whether tactical or strategic, may not necessarily be credible. Faced with growing internal cynicism and to restore the credibility of its deterrence posture, India may be contemplating new concepts, including the notion of counterforce pre-emptive first-strike against Pakistan for intimidation or as part of "dissuasion" ${ }^{64}$, which could be termed as sderzhivanie puten ustrasheniya - a Russian expression for 'deterrence through intimidation. ${ }^{, 65}$

If India wants to dissuade Pakistan from employing its short-range Nasr missiles by threatening a counterforce first-strike, it would need to build requisite ISR capabilities, besides acquiring nuclear sufficiency in numbers and precision, which it lacks at the moment. According to a recent study, India has fast-tracked its NWs' production, and may have already acquired the potential to build as many as 2,600 NWs, if it utilises

${ }^{64}$ Quinlan, Thinking about Nuclear Weapons: Principles, Problems, Prospects, 19. Dissuasion is a wider term than deterrence, covering all paths to convincing another party that it will not profit by a given course of action.

${ }^{65}$ Kristin Ven Bruusgaard, "Russian Strategic Deterrence," Survival: Global Politics and Strategy, 58, no. 4 (2016): 7-26 (8), https://doi.org/10.1080/00396338.2016.1207945. 
all of its unsafeguarded reactor-grade plutonium (RGPu) for bombmaking. ${ }^{66}$ Even with the world's third-largest nuclear inventory at its disposal, a counterforce first-strike against Pakistan cannot guarantee that India's major cities would be spared from substantial destruction.

India's credibility dilemma is self-inflicted as is reflected in various conflicting stipulations contained in its declaratory policy of 2003, and is a result of the widening gap between its declaratory policies and the ongoing nuclear developments. The problem has been further exacerbated due to perpetual dissonance amongst its strategic enclave, as all three principal stakeholders (political and military leadership, and its nuclear scientists) are moving on different trajectories. India needs to bridge the growing void between its declaratory policy and the nuclear capability - to restore the credibility of its deterrence posture. Without addressing these fundamental issues India's incoherent nuclear expansion would compel its adversaries to take remedial measures, thus, making it difficult to achieve lasting deterrence stability in the region. The country and its leadership need to bring clarity on some of the main elements of its nuclear policy, including its NFU and massive retaliation posture, besides quantifying its CMD requirements, to be seen as a credible nuclear weapon state

${ }^{66}$ Ahmed, "India's Nuclear Exceptionalism: Fissile Materials, Fuel Cycles and Safeguards." 